Original Article

\title{
Incidence and Trends of Neural Tube Defects in Babies Delivered at Dera Ghazi Khan Tertiary Care Center
}

\section{Syed Shahid Bokhari, Muhammad Asif Qureshi}

Departments of Neurosurgery and Pediatric Surgery, Ghazi Khan Medical College, Dera Ghazi Khan, Pakistan

\begin{abstract}
Objective: A cross-section study was conducted to determine the incidence and trends of neural tube defects in babies delivered at a tertiary care center. And those babies who were delivered elsewhere and were brought to a tertiary care center for treatment.
\end{abstract}

Material and Methods: The Study was conducted at neurosurgery and pediatric surgery departments, Ghazi Khan Medical College and Teaching Hospital. Two thousand $(n=2000)$ women delivered their babies at a tertiary care hospital were enrolled, out of them 52 women who delivered babies with neural tube defects (NTDs) were further assessed. Women were interviewed and history of folic acid intake, previous baby with NTDs and family history were recorded. Tests of significance were applied to assess the significant results.

Results: Folic acid intake was occurred in $n=298(14.9 \%)$ subjects. Association of folic acid on neural tube defects. Odds ratio showed that if a baby without intake of folic acid had 7.8 times at risk to suffer from a neural tube defect. The association was also significant $(p=0.000)$.

Conclusion: Neural tube defects are common in tertiary care centers its incidence was $2 \%$. Increased incidence of NTDs was observed in babies who delivered by folic acid deficit mothers. Early childhood marriages in rural areas and cousin marriages are the main contributing factors.

Keywords: Neural tube defect, Anencephaly, Spina bifida, Hydrocephalus, Meningocele.

Corresponding Author: Syed Shahid Bokhari

Department of Neurosurgery and Department of Pediatric Surgery, Ghazi Khan Medical College, Dera Ghazi Khan Email:bokhari787@gmail.com

Date of Submission: $17-11-2020$

Date of Revision: 06-12-2020

Date of Online Publishing: 25-12-2020

Date of Print: 30-12-2020

DOI: $10.36552 /$ pjns.v24i4.496

\section{INTRODUCTION}

Uttermost childhood health harm is congenital deformity including neural tube defects (NTDs). ${ }^{1}$ Neural tube defect defined as failure in the closure of the neural tube at the time of embryogenesis which may lead to the high proportion of mortality and morbidity in children. NTDs can be classified as "open" and "close" NTDs. In close NTDs neural tissue become 
covered with tissues and in open neural tissue exposed to tissues. ${ }^{2}$ A number of studies concluded that both environmental and genetic factors are responsible for NTDs. ${ }^{3}$

Recurrence risk of NTDs can be noticed easily in siblings of affected persons, in some syndromic person's cases of NTDs also observed due to chromosomal defects. ${ }^{4}$ The most common types of NTDs are multifactorial, which happened when genetic malformation occur due to environmental risk factors like parental occupation, socioeconomic status, radiation, drugs, chemicals, deficiency of folic acid and maternal nutritional status $^{5}$. All these factors have a strong contribution in occurring of such type of defects.

The worldwide incidence of NTDs is $1 / 1000$ births, but in total births it was $10 / 1000$ births. $^{6}$ Geographical, ethnic and racial zones have significant contribution in frequency of NTDs at the time of birth. ${ }^{7}$ The prevalence rate of NTDS is $1 \%, 0.6 \%, 11.4 \%$ in the United States, European republics and in India respectively. Beyond these states rural areas of China also have a high proportion of about 7.25 per 1000 births of NTDs. Similarly, in Saudi states it was found 0.78 per 1000 births in Southwestern, 6.9 per 1000 births in the region of Asir and 6.9 per 1000 in the Qassim region.8

A sharp decline in rate was observed from the last few years because of consequential elective abortions after anomaly scan at 20 weeks of pregnancy. ${ }^{9}$ Another major cause of decline of NTDs is the use of vitamin B12, along with folic acid or food supplementation to enhance the folic acid ratio from the early weeks of pregnancy. It was also reported that use of supplements to enhance the maternal folate ratio reduces the risk of NTDs upto $70 \%$. Many countries endorsed the health authorities to advise folic acid from the start of pregnancy to $12^{\text {th }}$ week of pregnancy to protect from NTDs. ${ }^{10}$

The current study was aimed to evaluate the incidence of neural tube defects in Pakistani population because of insufficient literature. This study will be an initiative towards modern research and will be helpful to fulfill the local reference gap.

\section{MATERIAL AND METHODS}

\section{Study Setting \& Sampling}

A cross-sectional study was conducted at neurosurgery and pediatric surgery departments DGKMC \& Hospital, Dera Ghazi Khan August 2019 to August 2020 in one year duration. The study was started after an ethical approval from the hospital ethical board and detailed information to patient. Two thousand ( $n=2000$ ) women delivered their babies at a tertiary care hospital were enrolled, out of them 52 women who delivered babies with neural tube defects (NTDs) were further assessed. Non probability consecutive sampling was the sampling technique. The sample size was calculated by using online software openepi.com.

\section{Inclusion Criteria}

All deliveries occurred during the study period and who were given consent was included in the study.

\section{Exclusion Criteria}

Fetuses died or terminated due to other causes were excluded from the study.

\section{Data Collection}

All patients were interviewed in detail about their history folic acid intake, previous NTDs was recorded in predesigned Performa. A type of neural tube defect, method of diagnosis and complications associated with NTDs in current pregnancy was recorded.

\section{Data Analysis}

SPSS version 23 was used for analysis of variables, 
mean and SD was calculated and presented for numerical variables like age and frequency and percentages were calculated and presented for categorical data like gender, type of NTDs, use of folic acid, method of diagnosis and mode of delivery. Tests of significance were applied to see the association among variables. $P$ value less than and equal to 0.05 was used as significant value.

\section{RESULTS}

From two thousand deliveries, the 52 (2.0\%) had neural tube defects.

\section{Age Incidence}

The mean age was of the women was $27.28 \pm$ 6.34 years. There were 27 (51.9\%) women between age $18-25$ years, 19 (36.5\%) between $26-40$ years and $6(11.5 \%)$ women $>40$ years of age.

Twenty five (48.1\%) patients had hydrocephalus, 10 (19.2\%) spina bifida with Meningocele, 6 (11.5\%) patients were anencephaly and multiple NTDs occurred in 9 (17.3\%) fetuses (Table 1).

Table 1: Demographic variables.

\begin{tabular}{|lcc|} 
Variable & Frequency & Percentage \\
$18-25$ (years) & 27 & 51.9 \\
$26-40$ (years) & 19 & 36.5 \\
$>40$ (years) & 6 & 11.5 \\
Hydrocephalus & 25 & 48.1 \\
Spina bifida with & 10 & 19.2 \\
Meningocele & 6 & 11.5 \\
Anencephaly & 9 & 17.3 \\
Multiple NTDs & & \\
\hline
\end{tabular}

\section{Clinical Information}

Neural tube defects were identified through labour in 12 (23.1\%) and at birth in 19 (36.5\%). While, during pregnancy, neural tube defects were identified through ultrasonography in 5 (9.6\%), X-Ray in 7 (13.5\%) and AFP in 5 (9.6\%)
(Table 2).

Mode of delivery of the women with neural tube defects babies was noted as spontaneous delivery $\mathrm{n}=15$ (28.8\%), normal delivery with encephalocentesis $n=19$ (36.5\%), breech delivery with encephalocentesis $n=15$ (28.8\%), caesarean section $n=6(11.5 \%)$ and hysterectomy in $n=3$ (5.8\%) women (Table 3).

Table 2: Method of diagnosis of neural tube defects.

\begin{tabular}{lcc} 
Variable & Frequency & Percentage \\
In Labour & 12 & 23.1 \\
At birth & 19 & 36.5 \\
During Pregnancy & & \\
Ultrasonography & 5 & 9.6 \\
X-Ray & 7 & 13.5 \\
AFP & 5 & 9.6 \\
\hline
\end{tabular}

Table 3: Mode of delivery in women having children with neural tube defects

\begin{tabular}{lcc} 
Variable & Frequency & Percentage \\
Spontaneous delivery & 15 & 28.8 \\
$\begin{array}{l}\text { Normal delivery with } \\
\text { encephalocentesis }\end{array}$ & 19 & 36.5 \\
$\begin{array}{l}\text { Breech delivery with } \\
\text { encephalocentesis }\end{array}$ & 15 & 28.8 \\
Caesarean section & 6 & 11.5 \\
Hysterectomy & 3 & 5.8 \\
\hline
\end{tabular}

Table 4: Association of intake of folic acid on neural tube defects.

\begin{tabular}{|lrrrr|} 
Neural Tube & \multicolumn{4}{c|}{ Folic Acid Intake } \\
Defects & Yes & No & Total & $\begin{array}{c}\text { p- } \\
\text { value }\end{array}$ \\
Neural tube defect & 8 & 6 & 14 & \\
Normal delivery & 290 & 1696 & 1986 & 0.000 \\
Total & 298 & 1702 & 2000 & \\
Odds ratio = 7.80 & & & & \\
\hline
\end{tabular}

During pregnancy Folic acid intake was being done by 298 (14.9\%) subjects. Association of folic acid on neural tube defects was shown in table 4. 
Odds ratio showed that if mother had not used folic acid then a baby had 7.8 times higher risk to suffer from a neural tube defect. The association was also significant, $p=0.000$ (Table 4).

\section{DISCUSSION}

In our study, a high incidence ratio of NTDs was observed, this is because of low education rate, lack of awareness and low socioeconomic status. Another major cause of high percentage in our study is the referral of patients from all peripheral areas in tertiary health care center. A study was conducted by Nicholas et $\mathrm{al}^{11}$ in 1998 and reported that folic acid deficiency is the leading cause of NTDs in patients that can be overcome by using folic acid supplements and fortified grains.

Rajab et $\mathrm{al}^{12}$ conducted a study on Omani population and concluded that like other factor high temperature environment is also a factor of NTDs that is the reason of the high incidence ratio of NTDs in Oman. Another leading cause of NTDs is a family history of NTDs that can be prevented by marrying out of close relationships. A similar study was conducted by Rasmussen et $\mathrm{al}^{13}$ and reported in his study that female who themselves have NTD or have had a child with NTD must use folic acid supplements with a dose of $5 \mathrm{mg}$ per day to avoid NTDs. It is also necessary to change food plan and shift on highest percentage of folic acid food from the start of pregnancy.

Michie et al ${ }^{14}$ completed a study in 1998 and reported that socioeconomic status is a cause of NTDs. In his study he observed Pakistani and Indian women belong to low socioeconomic status and compared with the general population. Another study was conducted by Khattak et al ${ }^{15}$ and observed that along with folic acid deficiency advance maternal age is also a contributing factor of NTDs. Early age marriage and good nutrition are key factors to reduce the chances of NTDs.
Algahtany $\mathrm{M}^{16}$ conducted another study on this topic in Saudi Arabia and concluded that male babies are at high risk of NTDs as compared to female babies. So, women bearing male baby should be taking strong preventive measures to avoid NTDs. A significant reduction in the proportion of NTDs was observed within 3-4 years. In a study by Asindi et $\mathrm{al}^{17}$ male dominance was not observed and concluded that there was no gender base difference regarding NTDs in babies.

In our study, we also compared the diagnostic methods of spina bifida and found ultrasonography is the better diagnostic method. Similarly Chan et al $^{18}$ observed in his study that the sensitivity of ultrasonography (anomaly scan) is much higher than serum AFP screening. Sensitivity of ultrasound is $86 \%$ and of serum AFP $72 \%$. In another study by Simpson et $\mathrm{al}^{19}$ indicated that serum AFP is expensive diagnostic measurement and available in all over the country, but ultrasonography is easily available and less costly diagnostic method.

Effect of drugs was also observed on NTDs and complications of NTDs on maternal life. Rothenberg et $\mathrm{al}^{20}$ completed a study on observation of use of antiepileptic drugs and incidence of NTDs. Use of sodium valproate and carbamazepine enhance the risk of spina bifida $1.5 \%$ as compared to non-epileptic women. Furthermore, placental abruption, rupture uterus and hysterectomy due to obstructed labor are common complications of NTDs.

\section{Limitations}

The limitation of this present study is that having been conducted in tertiary care teaching hospital, it doesn't represent the true incidence of NTDs at the community level. Detailed demographic study of the mothers', who have given birth to fetuses with NTDs analyzed in this study, has not been attempted. Being a retrospective study the folic acid status of women and the data regarding 
whether they took prenatal or perinatal folic acid supplementation could not be presented. The limitation of this present study is that having been conducted in tertiary care teaching hospital, it doesn't represent the true incidence of NTDs at the community level. Detailed demographic study of the mothers', who have given birth to fetuses with NTDs analyzed in this study, has not been attempted. Being a retrospective study the folic acid status of women and the data regarding whether they took prenatal or perinatal folic acid supplementation could not be presented. The limitation of this present study is that having been conducted in tertiary care teaching hospital, it doesn't represent the true incidence of NTDs at the community level.

\section{Recommendations}

Advanced maternal age, cousin marriage, malnutrition and lack of folic acid supplementation during pregnancy are the main contributing factors of NTDs. Community based awareness of these factors and counseling of patients recommended. Addition to this in remote areas of DG Khan there is a tribal family system; the early childhood marriages in such tribal system are also a factor, as mothers they are underage and are malnourished also.

\section{CONCLUSION}

Results of our study reveal that:

1. Neural tube defects are common in tertiary care centers its incidence was $2 \%$ observed.

2. Increased incidence of NTDs was observed in babies who delivered by folic acid deficit mothers.

3. Early childhood marriages in rural areas and cousin marriages are the main contributing factors.

\section{REFERENCES}

1. Estifanos D, Teages Adgoy ET, Sereke D, Zekarias B, Marzolf S, Tedla K. The Prevalence, Trend, and Associated Demographic Factors of Neural Tube Defects at Orotta National Referral Maternity Hospital, Asmara: Retrospective Record Review Study. Sci J Public Health. 2017; 5 (6): 452-456.

Doi: 10.11648/j.sjph.20170506.17

2. Zaganjor I, Sekkarie A, Tsang BL, Williams J, Razzaghi $H$, Mulinare $J$ et al. Describing the prevalence of neural tube defects worldwide: A systematic literature review. PloS one, 2016; 11; 11 (4): e0151586.

3. Liu J, Li Z, Greene NDE, Li H, Ren A. The recurrence risk of neural tube defects (NTDs) in a population with high prevalence of NTDs in northern China. Oncotarget. 2017; 8 (42): 72577-72583.

Doi:10.18632/oncotarget.19890

4. Turner MJ. Neural Tube Defects and Folic Acid Food Fortification in Europe. Am J Public Health, 2018; 108 (5): 601-602.

Doi:10.2105/AJPH.2018.304389

5. Chitayat D, Matsui D, Amitai Y. Folic acid supplementation for pregnant women and those planning pregnancy: 2015 update. J Clin Pharmacol. 2016; 56 (2): 170-175.

6. Viswanathan $M$, Treiman KA, Kish-Doto J, Middleton JC, Coker-Schwimmer EJ, Nicholson WK. Folic acid supplementation for the prevention of neural tube defects: an updated evidence report and systematic review for the US Preventive Services Task Force. JAMA. 2017; 317 (2): 190-203.

7. Atta $C A$, Fiest KM, Frolkis $A D$ et al. Global birth prevalence of spina bifida by folic acid fortification status: a systematic review and meta-analysis. Am J Public Health, 2016; 106 (1): e24-e34.

8. Khoshnood $B$, Loane $\mathrm{M}$, de Walle $\mathrm{H}$ et al. Long term trends in prevalence of neural tube defects in Europe: population based study. BMJ. 2015; 351: h5949.

9. Liu S, Evans J, MacFarlane AJ, et al. Association of maternal risk factors with the recent rise of neural tube defects in Canada. Paediatr Perinat Epidemiol. 2019; 33 (2): 145-153. Doi:10.1111/ppe.12543

10. Huang HY, Chen HL, Feng LP. Maternal obesity and the risk of neural tube defects in offspring: a metaanalysis. Obes Res Clin Pract. 2017; 11: 188-197. 
11. Nicholas JW. Folic acid food fortification to prevent neural tube defects. Lancet. 1998; 351: 1008-10.

12. Rajab A. Neural tube defects and congenital hydrocephalus in the sultanate of Oman. J Trop Paediatr. 1998; 44: 300-3.

13. Rasmussen LB. Folate and neural tube defects, recommendations from a Danish working group. Dan Med Bull. 1998; 45: 213-7.

14. Michie CA. Folate deficiency, neural tube defects and cardiac disease in U.K India and Pakistanis. The Lancet, 1998; 351: 1105-7.

15. Khattak ST, Naheed T, Akhter S, Jamal T. Incidence and risk factors for neural tube defects in Peshawar. Gomal J Med Sci. 2008; 6 (1): 1-4.

16. Algahtany $M$. Trends of neural tube defects incidence in Asir Province, Southern Region of Saudi Arabia. Pak Pediatr J. 2014; 38 (3): 156-60.
17. Asindi A, Al-Shehri A. Neural Tube Defects in the Asir Region of Saudi Arabia. Annals of Saudi Medicine, 2001; 21 (1-2): 26-29.

18. Chan A. The sensitivity of ultrasound and alpha fetoprotein in population based antenatal screening for neural tube defect, South Australia 1996 -1991. Br J Obstet Gynecol. 1995; 102: 370-6.

19. Simpson JL. Association between adverse perinatal out come and severally obtained second and third trimester maternal serum alpha feto protein measurement. Am J Obstet Gynecol. 1995; 173: 1742-8.

20. Rothenberg SP, Costa MP and Sequeira JM. Autoantibodies against folate receptors in women with a pregnancy complicated with neural tube defect. N Engl J Med. 2004; 350: 134-42.

\section{Additional Information}

Disclosures: Authors report no conflict of interest.

Human Subjects: Consent was obtained by all patient(s)/participant(s) in this study.

\section{Conflicts of Interest:}

In compliance with the ICMJE uniform disclosure form, all authors declare the following:

Financial Relationships: All authors have declared that they have no financial relationships at present or within the previous three years with any organizations that might have an interest in the submitted work.

Other Relationships: All authors have declared that there are no other relationships or activities that could appear to have influenced the submitted work.

\section{AUTHORS CONTRIBUTIONS}

\begin{tabular}{|l|l|l|}
\hline Sr.\# & Author's Full Name & Intellectual Contribution to Paper in Terms of: \\
\hline 1. & Syed Shahid Bokhari & 1. Study design, data collection and methodology. \\
\hline 2. & Muhammad Asif Qureshi & 2. Paper writing, referencing, and data calculations. \\
\hline
\end{tabular}

